\title{
Synopsis of Eulophia R.Br. (Orchidaceae) in Manipur (India) with a new distributional record to the state
}

\author{
Krishna Chowlu, A. Nageswara $\mathbf{R a o}^{2}$ and Chaya Deori ${ }^{3}$ \\ ${ }^{1}$ Botanical Survey of India, Arunachal Pradesh Regional Centre, Senki View, Itanagar 791111, Arunachal \\ Pradesh, India \\ 21-156, Rajarajeswari Nagar, Tangellamudi, ELURU-534005, West Godavari District, Andhra Pradesh, India \\ ${ }^{3}$ Botanical Survey of India, Eastern Regional Centre, Shillong-793003, Meghalaya, India \\ ${ }^{1}$ Corresponding author; e-mail: krishnachowlu@gmail.com
}

[Received 14.12.2020; Revised 16.12.2020; Accepted 19.12.2020; Published 31.12.2020]

\begin{abstract}
Seven species of Eulophia R.Br. (Orchidaceae) including one new distributional record to the state of Manipur vi₹., Eulophia macrobulbon (C.S.P. Parish \& Rchb.f.) Hook.f. are enumerated with latest nomenclature, phenology and distribution details. So far, the occurrence of E. macrobulbon in India (from Sikkim) has been doubtful because of no evidence of either herbarium or live collection data except a plate of line drawings deposited in CAL. Present report of E. macrobulbon from Manipur is the first authentic record from India. Detailed description, key with a colour plate is provided for easy identification of species.
\end{abstract}

Key words: Eulophia, Orchidaceae, E. macrobulbon, New record, Manipur.

\section{INTRODUCTION}

Manipur is one of the eight states of North-East India and strategically placed at the eastern end of the region between the latitude of $23^{\circ} 83^{\prime} \mathrm{N}-25^{\circ} 68^{\prime} \mathrm{N}$ and longitude of $93^{\circ} 03^{\prime} \mathrm{E}-$ $94^{\circ} 78^{\prime} \mathrm{E}$. The natural vegetation of Manipur falls under the Indo-Burma Biodiversity Hotspot area with rich flora and fauna (Singh et al. 2010). The orchid genus Eulophus established by R. Brown in 1821 was renamed as Eulophia and published as a conserved named by J. Lindley (1823). The genus is characterised by terrestrial, autotrophic or rarely mycotrophic habit, hypogeal fleshy rhizomes or tubers or rarely epigeal pseudobulbs, presence or absence of leaves during flowering, laxly to densely many flowered raceme or rarely panicle, 3-lobed lip with various ornamentation on disc and usually a small tubular or conical spur at base, column with or without a foot and 2 sub-globose pollinia.

Eulophia is one of the largest terrestrial genera in the family Orchidaceae consisting of about 200 species distributed in tropical and subtropical regions, most diverse in Africa, but also widespread from Madagascar and the Mascarene Islands to Central and tropical Asia, the SW Pacific islands, and North and NW Australia (Chen et al. 2009). In India, the genus is represented by 26 species (Misra 2019) of which 6 species are recorded from Manipur (Chauhan 2001; Kumar \& Kumar 2005; Nanda et al. 2014; Mao \& Deori 2018; Singh et al. 2019).

During a field trip in March, 2020, to Moreh surroundings of Tengnoupal district of Manipur, few Eulopbia plants in flowering stage were collected and brought under cultivation. Upon a critical study and based on the available literature (Reichenbach 1874; Hooker 1890; Pradhan 1979; Govaerts et al. 2020) the new collection has been identified as E. macrobulbon (Parish \& Rchb. f.) Hooker which was doubtfully known in India hitherto only from Sikkim (Hooker 1890). It may be mentioned that there is no record of any herbarium specimen of this species collected from Sikkim except a drawing plate deposited in CAL (Hooker 1895). 
Therefore, the present report of E. macrobulbon from Manipur is not only a new distributional record to the state but also provides an authentic data of herbarium and live collections confirming its occurrence in India. All the seven species of Eulophia found in Manipur are enumerated below with latest nomenclature, brief description and distribution data in addition to a detailed description and a colour plate of E. macrobulbon prepared from the fresh collections. An identification key also is provided for all the seven species.

\section{Key to the species of Eulophia R. Br. in Manipur}

1a. Plants mycotrophic, leaves totally absent E. zollingerii

1b. Plants autotrophic, with green leaves

2a. Plants with green epigeal pseudobulbs, Inflorescence branched

2b. Plants with underground rhizomes, inflorescence unbranched E. graminea

3a. Leaves present when plant in flowering 3

3b. Leaves absent when plant in flowering

4a. Column with foot, leaves elliptic-lanceolate, acute, $29-40 \mathrm{~cm}$ long .........E. nuda

4b. Column without foot, leaves linear-oblong, acuminate, $60-90 \mathrm{~cm}$ long .. $\boldsymbol{E}$. mannii

5a. Underground rhizomes 3-4, globose, arranged in linearly

5b. Underground rhizome single, horizontal, oblong..

E. macrobulbon

6a. Column with foot, spur of lip small conical

6b. Column without foot, spur of lip long, tubular E. bicallosa

E. dabia

\section{ENUMERATION}

Eulophia bicallosa (D. Don) Hunt \& Summerh., in Kew Bull. 20: 60. 1966; Chauhan in Pathak, Sehgal, R. N., Shekar, N., Sharma, M. \& Sood, A. (eds.), Orchid Science \& Commerce: 91. 2001; Kumar \& Kumar, in Rheedea 15 (1): 39. 2005; A. N. Rao \& V. Kumar, in Turczaninowia 21(4): 119.2018; A. A. Mao \& C. Deori, Check-list Orch. Manipur: 78. 2018. Bletillabicallosa D. Don, Prodr. Fl Nepal: 30. 1825. Cyrtopera bicarinata Lindl., Gen.Sp. Orchid. Pl.: 190. 1833. Eulophia bicarinata (Lindl.) Hook. f., Fl. Brit. India 6: 6. 1890. Eulophia candida (Lindl.) Hook. f., Fl. Brit. India 6: 6.1890; Mukerjee, in Notes Roy. Bot. Gard. Edinburgh 21 (3): 152. 1953.

Flowering \& Fruiting: March June.

Occurrence in Manipur: Ukhrul dist., Chammu, 1300m., S.K. Mukerjee 3023 (CAL).

Distribution: India (Arunachal Pradesh, Manipur), Nepal, Myanmar, Thailand, Taiwan, Sumatra, New Guinea, Australia.

Eulophia dabia (D. Don) Hochr., in Bull. New York Bot. Gard. 6: 270. 1910; Chauhan in Pathak, P., Sehgal, R.N., Shekar, N., Sharma, M. \& Sood, A. (eds.) Orchid Science \& Commerce 91. 2001; Kumar \& Kumar, in Rheedea 15 (1): 39. 2005; A. N. Rao \& V. Kumar, in Turczaninowia 21(4): 119. 2018; A.A. Mao \& C. Deori, Check-list Orch. Manipur: 78. 2018. Bletiadabia D. Don, Prodr. Fl. Nepal. : 30. 1825. Eulophia campestris Wall. ex Lindl., Gen. Sp. Orchid. Pl.: 185.1833; Mukerjee, in Notes Royal Botanic Garden Edinburgh 21 (3): 52. 1953; Deb, in Bull. Bot. Surv. India 3(3): 127. 1961.

Flowering \& Fruiting: May - June

Occurrence in Manipur. Ukrul, 1800 m, S.K. Mukerjee 2717 (CAL).

Distribution: India (Arunachal Pradesh, Manipur), Afganisan, Pakistan, Myanmar, China.

Eulophia graminea Lindl., Gen. Sp. Orchid. Pl.: 182.1833; A. A. Mao \& C. Deori, Check-list Orch. Manipur: 79. 2018. E. ucbii Malhotra \& Balodi, in Bull. Bot. Surv. India 26: 92 (1984 publ. 1985). 


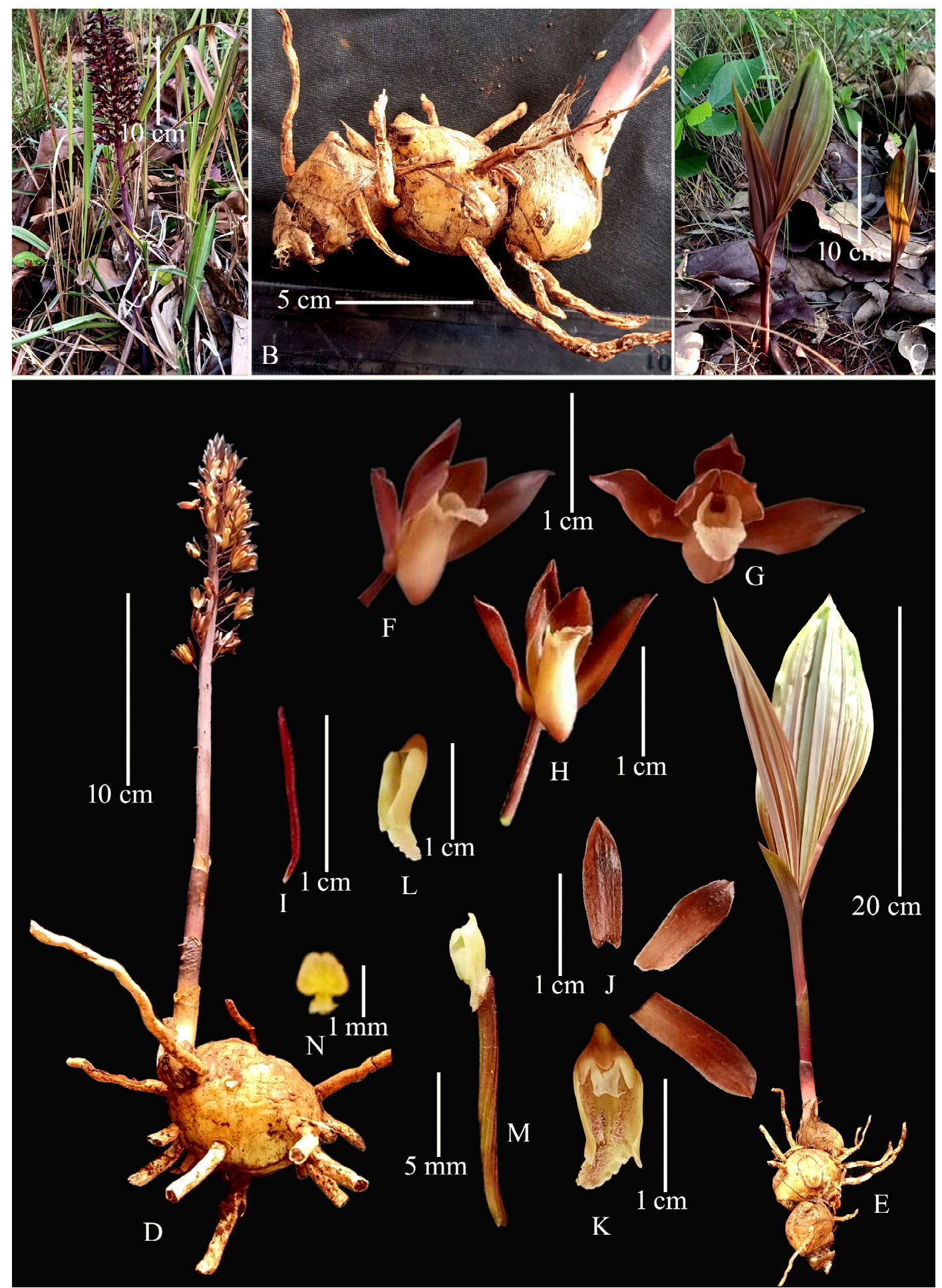

PLATE I. Eulophia macrobulbon (Parish \& Rchb. f.) Hook. f.: A. Plant in natural habitat; B. Underground tubers; C. Plant in leaf stage in natural habitat; D. Plant in flowering stage; E. Plant in leaf stage; FH. Flower- lateral \& front view; I. Bract; J. Sepal \& Petal; K. Lip (front view); L. Lip (side view); M. Pedicellate ovary and Column; N. Pollinarium. 
Flowering \& Fruiting: May - June

Occurrence in Manipur. Yangoupokpi Lokchao Wild Life Sanctuary, KhujaiLok, Tengnoupal district, Moreh, $412 \mathrm{~m}$, Chowlu 41803 (ARUN).

Distribution: India: (Arunachal Pradesh, Manipur), China, Myanmar; Thailand. Malaysia, Sumatra.

Eulophia macrobulbon (Parish \& Rchb.f.) Hook.f., Fl. Brit. India 6: 7.1890. Cyrtopera macrobulbon Parish \& Rchb. f. in Trans. Linn. Soc. London 30: 144. 1874. Eulophia burmannica Hook.f., Fl. Brit. India 6: 5. 1890.

Plants terrestrial, up to $45 \mathrm{~cm}$ tall. Underground tubers ovoid to spherical, $4-9 \times 2-4 \mathrm{~cm}$, arranged in horizontal row, 2-3 noded, producing long thick roots from basal half. Stem formed with sheathing leaf bases, erect, up to $1 \mathrm{~cm}$ thick, covered with 2 tubular sheaths towards base. Leaves $2-3$, unequal, strongly plaited, purplish green on upside and purple beneath, appearing after the flowering stage; large leaf $20-27 \times 6.5-8.0 \mathrm{~cm}$, broadly elliptic, acute or apiculate; middle leaf 19-24 $\times 4-6 \mathrm{~cm}$, narrowly elliptic lanceolate, acuminate , lowest leaf smaller, $57 \times 2.5-4 \mathrm{~cm}$, ovate, acute. Inflorescence erect, $28-37 \mathrm{~cm}$ long, densely many flowered; peduncle robust, terete, reddish purple, with 35 tubular clasping sheaths at small intervals towards base. Floral bracts $1.0-1.2 \times 0.3-0.4 \mathrm{~cm}$, as long as the pedicellate ovary, linear oblong, acute to acuminate, maroon. Flowers many, about $1 \mathrm{~cm}$ across, reddish brown with pale yellow lip; pedicel and ovary 1-1.4 cm long, glabrous. Sepals subequal, spreading, oblong lanceolate, straight acute or shortly apiculate at apex; dorsal sepal 1.2-1.5 $\times 0.35-0.5$ $\mathrm{cm}$, laterals slightly longer than dorsal, slightly falcate. Petals $0.81 .2 \times 0.50 .6 \mathrm{~cm}$, oblong lanceolate, acute to apiculate, Lip 1.5-1.7 × 0.7-0.8 cm, creamy yellow, 3 lobed; lateral lobes erect, oblong, obtuse; mid lobe ovate, subacute, undulate at margins, recurved; disc with two rows of purplish crenate ridges running from the base of lip to base of lateral lobes and join with 3 crenate ridges on middle region; spur short, 3-4 mm long, conical, obtuse,reddish brown. Column erect, 4-5 mm long, pale yellow. Anther cap short, 1.5-2.0 $\mathrm{mm}$ long, ovate, with obtusely bifid projection at top, reddish brown. Pollinia 2, sub-triangular, 1-1.5 mm long, porate, yellow, with oblong caudicle and ovate viscidium.

Flowering \& fruiting: March - June.

Occurrence in Manipur: India, Manipur, Tengnoupal district, Moreh, $412 \mathrm{~m}$, Chowlu 42802 (ARUN).

Distribution: India (Arunachal Pradesh), Myanmar, Thailand, Laos, Vietnam.

Eulophia mannii (Rchb.f.) Hook. f., Fl. Brit. India 6: 4.1890 \& Icon. Pl. ser. 4 (22): t. 2115. 1894; A.N. Rao \& V. Kumar in Turczaninowia 21(4):119.2018. Cyrtopera mannii Rchb.f., Flora 55: 274. 1872.

Flowering \& Fruiting: June - August.

Occurrence in Manipur: Tummo Hill, Prazer 155 (CAL).

Distribution: India: (Assam, Manipur, Sikkim, West Bengal).

Eulophia nuda Lindl., Gen. Sp. Orchid. Pl.: 180. 1833. Chauhan in Pathak, P., Sehgal, R.N., Shekar, N., Sharma, M. \& Sood, A. (eds.) Orchid Science \& Commerce 91: 2001; A.N. Rao \& V. Kumar, in Turczaninowia 21(4): 119. 2018. Eulophia spectabilis Suresh in D.H. Nicolson, C.R. Suresh \& K.S. Manilal, Interpr. Van Rheede's Hort. Malab.: 300. 1988, nom. Superfl; Kumar \& Kumar in Rheedea 15 (1): 39. 2005; A.A. Mao \& C. Deori, Check-list Orch. Manipur.: 79. 2018. Flowering \& Fruiting: April July.

Occurrence in Manipur. Senapati district, Kangpokpi; sine loc., N.L. Bor 17986 (ASSAM).

Distribution: India (Arunachal Pradesh, Manipur); China, Indonesia, Malaysia, New Guinea, Philippines, Sri Lanka. 
Eulophia zollingeri (Rchb.f.) J.J. Sm., Orch. Java: 228.1905; Nanda et al. in Bull. Bot. Surv. India 56: 248. 2014; A. N. Rao \& V. Kumar, in Turczaninowia 21(4): 119. 2018; A.A. Mao \& C. Deori, Checkl. Orch. Manipur: 79. 2018. Cyrtopera zollingeri H.G. Reichenbach in Bonpalandia 5: 38. 1857. Cyrtopera sanguine Lindl., in J. Proc. Linn. Soc., Bot. 3: 32. 1858. Eulophia sanguine (Lindl.) Hook.f., Fl. Brit. India 6: 8. 1890.

Flowering \& Fruiting: June - July.

Occurrence in Manipur: Senapati district, Hengbung, 1252 m, Akimpou 00531(COGCEHR Herbarium, Hengbung, Manipur).

Distribution: India (Arunachal Pradesh, Manipur, Meghalaya, Sikkim, West Bengal, Karnataka \& Kerala), Australia, China, Indonesia, Japan, Malaysia, New Guinea, Philippines, Thailand.

\section{Acknowledgements}

The authors are grateful to A.A. Mao, Director, Botanical Survey of India for providing logistic support. Chaya Deori is thankful to N. Odyuo, Scientist-E, Head of Office, Botanical Survey of India, Eastern Regional Centre, Shillong for encouragement and facilities. Also special thanks to Mr. Soniyal for the help rendered in the field.

\section{LITERATURE CITED}

Brown, R., 1821. Lissocbilus speciosus. Mr. Griffin’s Lissochilus. Edwards's Botanical Register 7: 573.

Chauhan, A.S. 2001. A conspectus of Orchids of Manipur: Their status and conservation. In Pathak, P.; Sehgal, R. N.; Shekar, N; Sharma, M.\& Sood, A. (Eds.) Orchids: Science and Commerce. Bishen Singh and Mahendra Pal Singh, Dehra Dun, pp. 81 - 99.

Chen, X.; Cribb, P.J. \& Gale, S.W. 2009. 68 p. 101 plates. Eulophia R.Br. in In: Wu, Z.Y., Raven, P.H. \& D.Y. Hong (eds), Flora of China 25 (Orchidaceae). Science Press, Beijing, and Missouri Botanical Garden Press, St. Louis. pp. 253 - 258.

Govaerts, R.; Bernet, P.; Kratochvil, K.; Gerlach, G.; Carr, G.; Alrich, P.; Pridgeon, A.M., Pfahl, J.; Campacci, M.A.;Baptista, D.H.; Tigges, H.; Shaw, J.; Cribb, P.; George, A.; Kreuz, K.\& Wood, J. 2020. World checklist of Orchidaceae. Facilitated by the Royal Botanic Gardens, Kew. Available at: http://apps.kew.org/wcsp/ (Accessed on 20.05.2020).

Hooker, J.D. 1890. Orchidaceae. in: The Flora of British India, vol. 6. Reeve, London, pp. $1-198$.

Hooker, J.D. 1895. A Century of Indian Orchids. Annals of Royal Botanic Garden Calcutta 5: $1-68 \& 101$ plates.

King, G. \& Pantling, R. 1898. The Orchids of Sikkim Himalaya. Annals of the Royal Botanic Garden, Calcutta 8: 1 - 342.

Kumar, C.S. \& Kumar, P.C.S. 2005. An Orchid Digest of Manipur, North-eastern India. Rheedea 15(1): 1 - 70.

Lindley, J., 1830 - 1840. Genera and Species of Orchidaceous Plants. London. pp. 1 - 553.

Mao, A.A. \& Deori, C. 2018. Checklist of Orchids of Manipur-A pictorial handbook. Forest Department, Government of Manipur and Botanical Survey of India, Government of India.

Misra, S. 2019. Orchids of India. A Handbook. Bishen Singh and Mahendra Pal Singh, Dehra Dun.

Nanda Y., Chowlu, K. \& Rao, A.N. 2014. Eulophia zollingeri and Pelatantheria insectifera two new additions to the orchid flora of Manipur. Bull. Bot. Surv. India 56: 248 - 251. 
366 Synopsis of Eulophia in Manipur

Pathak, P., Sehgal, R.N., Shekar, N., Sharma, M. \& Sood, A. 2001. Orchid Science \& Commerce. Bishen Singh Mahendrapal Singh, Dehra Dun.

Pearce, N.R. \& Cribb, P. J. 2002. The orchids of Bhutan. Royal Botanic Garden Edinburgh\& Government of Bhutan. Pp. $1-643$.

Pradhan, U.C. 1979. Indian Orchids: Guide to Identification and Culture. Vol. 2. Kalimpong. pp. $190-747$.

Rao, A.N. \& Kumar, V. 2018. Updated checklist of Orchids of Manipur. Turczaninowia 21(4): $109-134$

Rao, A.S. \& Hajra, P.K. 1974. Eulophia mannii Hook. f. - a scarcely known ground orchid from Assam. Bull. Bot. Surv. India 16(1-4): $156-157$.

Reichenbach, H.G. 1874. Enumeration of the orchids collected by the Rev. E. C. Parish in the neighbourhood of Moulmein, with descriptions of the new species. Trans. Linn. Soc. London 30(1): 133 - 155.

Singh, E.J.; Singh, N. K. S. \& Singh, N. R. 2010. Biodiversity conservation and natural resources in North East India-with special reference to Manipur. NeBIO 1(1): 42 - 47.

Singh, S.K.; Agrawala, D.K; Jalal, J.S.; Dash, S.S.; Mao, A.A. \& Singh, P.2019. Orchids of India- $A$ pictorial guide. Botanical Survey of India, Kolkata. pp. $1-548$ 